\title{
Algılanan Özerklik ve Etki İle Psikolojik Sahiplenme Arasındaki İlişkide Kontrol Algısının Aracılık Etkisi: Banka Çalışanları Üzerinde Bir Araştırma
}

\author{
In Relationship Among Perceived Autonomy-Impact and Psychological \\ Ownership The Mediating Effect Of Perceived Control: A Research on \\ Banking Employees
}

\begin{abstract}
ÖZET
Psikolojik sahiplenme, yasal düzlemde sahiplikleri olmamasına rağmen işgörenlerin iş ve örgütlerine yönelik sahiplenme hissedebileceğini ifade etmektedir. İ̧ini ve örgütünü psikolojik bağlamda sahiplenen işgörenlerin olumlu duygu, tutum ve davranışlar sergiledikleri araştırmalara sıklıkla konu olmaktadır. Ancak psikolojik sahiplenme olgusuna ilişkin bir teorinin oluştuğunu söylemek güçtür ve daha fazla ampirik araştırmanın kuramsal çalışmaları doğrulaması gerekmektedir. Özellikle de psikolojik sahiplenme olgusunu ortaya çıkaran öncüllerin neler olduğu ve olguyu ne şekilde etkilediğinin araştırılması önemlidir. Bu çalışmanın amacı algılanan özerklik ve etki ile psikolojik sahiplenme arasındaki ilişkiyi incelemek ve bu ilişkide kontrol algısının aracilık etkisinin olup olmadığını belirlemektir. Veriler, anket aracılığıyla Bitlis ve Bitlis bağlı Tatvan ilçesinde bankacilık sektöründeki örgütlerde çalışan 158 katılımcıdan elde edilmiştir. Araştırma sonucunda özerlik algısı ile psikolojik sahiplenme arasındaki ilişkide karar kontrolün tam araclık etkisi olduğu bulgulanmıştır.
\end{abstract}

Anahtar Kelimeler: Psikolojik Sahiplenme; Özerklik, Etki; Algılanan Kontrol

\section{GíRiş}

Çalışma yaşamı içerisinde üstlenmiş olduğu görevi iyi bir biçimde ifa eden işgörenler için "kendi işiymiş gibi çalışıyor" ya da "işyerini sahiplenmiş" gibi ifadelerin kullanıldığı bilinmektedir. Bununla birlikte uygulamacılar ve giderek artan sayıda örgüt bilimci belirli haklara bağlı olarak işgörenlerin yapmış olduk-

\begin{abstract}
Psychological ownership, although there is no in the legal context ownership, express that employees can feel ownership for their work and organizations. It is subjected in various researches that Employees who feel ownership towards their work and organization have frequently exhibited positive emotions, attitudes and behaviors. However, it is difficult to say that a theory about phenomenon of psychological ownership is formed and the theoretical studies should be verified by more empirical research. Especially, it is important to study which antecedents revealed the psychological ownership phenomenon and how they affected the phenomenon. The purpose of this study is both to examine the relationship between perceived autonomy and impact, and psychological ownership and to determine whether there is mediation effect of perceived control on this relationship. The data is collected from 158 employees who work banking sector in Bitlis and Tatvan. The findings of analysis indicated that control decision fully mediates the relationship beetwen perceived autonomy and psychological ownership.
\end{abstract}

Keywords: Psychological Ownership; AutonomyImpact; Perceived Control ları iş ve çalışmakta oldukları örgüte karşı sahiplenme hissettiklerini sıklıkla dile getirmektedir (Pierce vd., 2004: 507). Dış yazında "psychlogical ownership" (psikolojik sahiplenme) olarak kavramlaştırılan bu olgu, son dönemde örgüt bilimlerindeki araştırmalara konu olurken, işgörenlerin çalışmış oldukları örgüte karşı duygu, tutum ve davranışları bağlamında zengin bir 
içerik sağlamaktadır. Nitekim psikolojik sahiplenme (PS) olgusunu örgütsel bağlamda ele alan bir çok araştırmada (örn., Pierce vd., 2001; Dirks, 2003; Pierce vd., 2004; Pierce ve Rodgers, 2004; Van Dyne ve Pierce, 2004; Mayhew vd., 2007, Özler vd., 2008; Ötken, 2015, Yıldız vd., 2015, Uçar, 2016) örgütlerine karşı psikolojik bağlamda sahiplenme hisseden işgörenlerin olumlu duygu, tutum ve davranışlar sergiledikleri yönünde ortak bir bakış açısının olduğu anlaşılmaktadır.

Sahiplik kavramı üzerine yapılan ilk araştırmaların finansal sahiplik (financal ownership) bağlamında ele alındığı görülmektedir. Özü işgöreni çalışmış olduğu işyerinin hisselerine ortak yapma planlarına dayanan bu çalışmalarda temel amaç; işgörenlerin moral, motivasyon ve performanslarını arttırmaya çalışmaktır (Vandewalle vd., 1996:210). Ancak finansal sahipliğe ilişkin araştırma sonuçlarını toplu olarak değerlendiren Pierce ve Furo (1991) elde edilen sonuçlarla istenilen sonuçlar arasında tutarsızlıklar tespit etmiş ve finansal sahipliğin her koşulda olumlu işgören tutum ve davranışı ortaya çıkartmayacağı sonucuna ulaşmıştır. Pierce ve Furo'ya (1991) göre işgörenlerin psikolojik bağlamda sahiplenme hissetmeleri için sahipliğin doğasında var olan bir takım haklarından yararlanmaları gerekmektedir. Bu tespitten hareketle Psikolojik Sahiplenme kavramını ortaya koyan Pierce vd. (1991), yasal sahiplik durumu olmadan da işgörenlerin işlerine ve örgütlerine karşı sahiplenme hissi geliştirebileceklerini iddia etmiştir.

Toplam örgütsel başarının bireysel çıktılara bağlı olduğu düşünüldüğünde, genel olarak pozitif örgütsel davranışlarla ilişkilendirilen psikolojik sahiplenme olgusunun, yönetim bilimciler için önemli bir araştırma alanı olduğu ve uygulayıcılar için ise üzerinde önemle durulması gereken bir konu olduğu ortaya çıkmaktadır. Dolayısıyla işgörenin işini ve örgütünü sahiplenmesinin altında yatan temel dinamiklerin ortaya konması gerekmektedir. Her ne kadar psikolojik sahiplenmenin öncülleri üzerine keşifsel ve kavramsal düzeyde yapılan araştırmalar (Dirks, 2003; Pierce vd., 2004; Pierce ve Rodgers, 2004; Van Dyne ve Pierce, 2004; Mayhew vd., 2007, Yıldız vd., 2015, Ötken, 2015, Uçar, 2016) yazında var olsa da Avey'in (2009) de belirmiş olduğu gibi psikolojik sahiplenmeye ilişkin sağlam bir teorinin oluşabilmesi için kuramsal bağlamdaki araştırmaların ampirik araştırmalarla sınanması gerekmektedir. Nitekim psikolojik sahiplenmenin oluşumunda bireyin etkinlik, özerklik ve kontrol algılarının önemli olduğunu ortaya koymasına karşın, alan yazının bu savları destekleyecek yeterli ampirik araştırmalarla doygunluğa ulaştığı söylenemez. O nedenle bu çalışmada kuramsal bağlamda psikolojik sahiplenme olgusunu etkilediği iddia edilen özerklik ve etki değişkenlerinin PS ile ilişkisinde, kontrol algısı değişkeninin aracılık etkisinin araştırılması amaçlanmıştır. Bu amaçla örgütsel davranış, psikoloji ve sosyoloji yazınları araştırma özelinde incelenmiştir. Araştırma sonucunda, kavramsal ve kuramsal düzeyde yazının da üzerinde sıklıkla durmuş olduğu gibi kontrolün psikolojik sahiplenme üzerinde etkisi ampirik bir araştırmayla ortaya konmuştur.

\section{YAZIN TARAMASI}

\subsection{Psikolojik Sahiplenme Kavramı}

Örgütsel alana ilişkin sahiplik olgusu araştırmalarını 1970 öncesi dönem, 1970-1990 arası dönem ve 1990 sonrası dönem olmak üzere üç kısımda ele almak mümkündür. Catherine Webb, 1912 yılında yayınlamış olduğu çalışmada işgörenlerin çalışmış oldukları işyerlerine ortak yapılarak daha gayretli, hevesli ve dikkatli çalışmalarına ilişkin güdülerinin harekete geçirebileceğini iddia ederken; finansal sahipliğin çalışanlar üzerinde psikolojik farklılaşma yaratması sayesinde (Vandewalle vd., 1996: 210), işgörenlerin sergilemiş olduğu olumsuz tutum ve davranışlarda da olumlu yönde değişimler yaşanacağı düşünülmüştür (Pierce vd., 1991: 121). Dolayısıyla sahiplik olgusu üzerine yürütülen çalışmaların işgörenlerin çalışmakta oldukları işyeri hisselerine ortak yapılması planlarına dayanan finansal sahiplik araştırmalarıyla başladığı söylenebilir. Bu dönem araştırmaları genel olarak işgören devir hızı, devamsızlık, şikâyetleri azaltma, işgören yabancılaşması, örgütsel etkililik gibi işyerlerinde var olan temel problemlerin çözümüne odaklandığı görülmektedir.

1970 sonrası dönemde ise araştırmaların merkezine pozitif işgören tutum ve davranışlarının yerleştiği belirtilmektedir. (Pierce vd. 1991; Pierce ve Furo, 1991). Dolayısıyla finansal sahiplik çalışmalarının psikolojik çıktılara yöneldiği söylenebilir. Bu süreç içerisindeki çalışmaları ele alan Pierce vd. (1991) yazında var olan araştırmaların dağınık bir görüntü sergilediğini bildirirken; işgören sahipliğinin iş gören tutum ve davranışı üzerine etkisini süreçleyen iyi ve gelişmiş kavramsal ve teorik alt yapının gerekli olduğunu da belirtmişlerdir (Pierce vd., 1991: 122). Bu amaçla finansal sahiplik ile işgören tutum ve davranışları arasındaki ilişkileri konu alan araştırmaları bir bütün olarak inceleyen Pierce ve Furo (1991) işgörenlerin çalışmış oldukları 
işyeri hisselerine sahip yapılma planlarının, işgörenlerin olumlu tutum ve performansları üzerinde değişik sonuçlar ortaya çıkardığını bulgulamıştır. Sorunun nedenlerini anlama çabası içerisine giren Pierce ve Furo'nun (1991), finansal sahiplik planlarının hangi koşullarda olumlu tutum ve davranışsal çıktılar üretebileceği sorusuna yanıt aradıkları anlaşılmaktadır. Araştırmada yasal sahiplikle eşdeğer olarak görülen finansal sahipliğin, yasal sahipliğin içermiş olduğu hakları bireye tanımadığında, sahipliğin duygusal düzeye ulaşamayacağı sonucu ortaya konmuştur. Bu bağlamda yasal sahiplik yazınını inceleyen Pierce vd. (1991) yazının, yasal sahipliği genel olarak üç temel hak üzerinden tanımlandığını belirtmektedirler. Bu haklar 1) nesnenin fiziksel ve/veya finansal değeri üzerinde bir kısım hisselere sahip olma hakkı, 2) sahip olunan nesne üzerindeki kullanma (kontrol) hakkı, 3) sahip olunan nesne hakkında bilgi alma hakkı olarak tanımlanmaktadır (Pierce vd., 1991: 125). Araştırmacılara göre bu haklar sahipliğin duygusal yönünü geliştirmektedir. Dolayısıyla bu haklar işgörene tanınmadığında finansal ortaklık planları istenilen sonuçlara ulaşmamaktadır. Bu sonuçla birlikte psikolojik bağlamı temel alan üçüncü dönem araştırmalarının başlandığı izlenirken, finansal sahiplik iddiası olmadan da (sahipliğin kişiye sağlamış olduğu haklar üzerinden) işgörenlerin işlerine ve örgütlerine karşı sahiplenme hissedebilecekleri ortaya çıkmıştır.

Örgütsel bağlamda psikolojik sahiplenme araştırmalarının kökeni insan gelişimi, psikoloji ve sosyoloji yazınlarına dayanmaktadır. Ancak örgüt araştırmalarındaki yeri psikolojik kökeni temsil eden çalışmalar ekseninde gelişmiştir. Etizoni (1991: 465) ve Pierce vd. (1991: 124) göre sahiplik, kendi doğasında çok boyutlu bir yapıya sahiptir. Bu boyutlar yasal (formal, objective) sahiplik olgusu ve psikolojik bağlamda deneyimlenen sahiplik olgularıdır. Ancak Pierce vd. (2003: 5-6) bu düzeyleri ilişkili görmesine rağmen, yasal sahiplik ve psikolojik sahiplenme arasında önemli farklıııların olduğunu belirtmektedirler. Araştırmacılar göre yasal sahiplik kamusal bağlamda yasal dayanaklara sahipken, psikolojik sahiplenme ise kişisel bağlamda sahip olunan hislere dayanmaktadır.

Psikolojik sahiplenme, belirli koşullar altında işgörenlerin çalışmış oldukları örgüte ve çeşitli örgütsel faktörlere ilişkin geliştirdikleri sahiplik hissi olarak tanımlanmaktadır (Pierce vd., 2004: 511). Mahhew vd. (2007: 477) ise PS'yi mülkiyet hakkının resmi ya da yasal iddiasının yokluğundaki sahiplenme duygusu olarak tanımlamaktadır. Bir diğer tanımda Vandewalle vd. (1995: 211) PS'yi, “işgörenlerin yasal ya da finansal bir sahiplikleri olmamasına rağmen iş ve örgütlerine karşı sahiplenme duyguları hissetmelerini temsil etmektedir." şeklinde ifade etmektedir.

Bununla birlikte psikolojik sahiplenmenin örgütsel alana ilişkin farklı araştırma konularıyla da ele alındığı görülmektedir. İşgören üzerinde psikolojik sahiplenme hissini ortaya çıkaran güdüleyicilerin neler olduğu üzerine yoğunlaşan araştırmalar (Dirks, 2003; Pierce vd., 2004; Pierce ve Rodgers, 2004; Van Dyne ve Pierce, 2004; Mayhew vd., 2007), dönüşümcü liderlik-PS ilişkisi (Avey vd., 2009; Ghafoor vd., 2011; Bernhard ve O'Driscoll, 2011), edimsel liderlik-PS ilişkisi (Bernhard ve O'Discroll, 2011), etik liderlik-PS ilişkisi (Avey vd., 2012), yardımsever liderlik-PS ilişkisi (Zhu vd., 2013), hizmetkar liderlik-PS ilişkisi, (Yıldız ve Yıldız, 2015) ekstra rol davranışı-PS ilişkisi (Van Dyne ve Pierce, 2004; O'Driscoll vd., 2006; Avey vd., 2009; Bernhard ve O'Driscoll, 2011; Liu vd., 2012; Zhu vd., 2013; Van Dyne vd., 1995; VandeWalle vd., 1995) Örgüt yapı ve özellikleri-PS ilişkisi (Pierce vd., 2003), daha az yapılandırımış iş çevresi-PS ilişkisi (O'driscoll vd., 2006), kontrol-PS ilişkisi (Pierce vd., 2001; Pierce vd., 2003; O'driscoll vd., 2006; Pierce vd., 2009; Lee ve Chen, 2011) özerklik-PS ilişkisi (O'driscoll vd., 2006; Pierce vd., 2009; Mathew vd., 2007; Olckers ve DuPlessis, 2012), kompleks iş yapıları-PS ilişkisi (Pierce vd., 2009), bireylerin iş ve örgütleriyle bütünleşmeleri-PS ilişkisi (Ghafoor vd., 2011), bilişsel ve duygusal değer biçme-PS ilişkisi (Lee ve Chen, 2011), ruhsal ve duygusal zeka-PS ilişkisi (Kaur vd., 2013), işten ayrılma niyeti ve PS ilişkisi (Benhard ve O'Discroll, 2012), kültürel ve bireysel unsurlar-PS ilişkisi (Pierce vd., 2003), ait hissetme ihtiyacı-PS ilişkisi (Asatryan ve Oh, 2008; Ghafoor vd., 2011), idealizm-PS iliykisi (Yıldız ve Yıldız, 2015), hedefe odaklanma-PS ilişkisi (Lee ve Chen, 2011), sorumluluk-PS ilişkisi (Ghafoor vd., 2011), PS-yapıcı anormal davranışlar ilişkisi (Yıldız vd., 2015), katılım/finansal sahiplik planlarına katılım/ kararlara katılım -PS ilişkisi (Pare vd., 2006; Pare ve Sicotte ,2008; Asatryan ve Oh, 2008; Chi ve Han, 2008; Han vd., 2010; Liu vd., 2012; Wagner vd., 2003; Chi ve Han, 2008, Yıldız ve yıldız, 2015), performans-PS ilişkisi ( Pierce vd., 2009; Sieger vd., 2013; Wagner vd., 2003; Ghafoor vd., 2011), bilgi paylaşımı-PS ilişkisi Han vd., 2010), örgütsel adalet-PS ilişkisi (Atalay ve Özler, 2013, Ötken, 2015; Yıldız ve Yıldız, 2015), güvenPS ilişkisi (Brown vd., 2014), kişi-örgüt uyumu-PS ilişkisi (Yıldız ve Yıldız, 2015) üzerine yoğunlaşmıştır. Buna ek olarak, PS ile ilgili teori geliştirme kaygısı ile hareket eden araştırmalar (Pierce vd., 2001; Van Dyne 
ve Pierce, 2004; Avey vd., 2009; Pierce vd., 2010) da bulunmaktadır.

Çalışmada bu kısma kadar genel olarak psikolojik sahiplenme yazını incelenmiştir. Sonraki kısımlarda araştırmanın kuramsal alt yapısı ve ampirik bulguları ele alınacaktır.

\subsection{0̈zerklik (Self-determination), Etki (Impact) ve Kontrol Algısı Kavramları}

Özerklik ve etki değişkenleri genel olarak psikolojik güçlendirme başlığı altında araştırmalara sıklıkla konu olmaktadır. Örgüt içerisinde bireyin insiyatif alabilme ve bunun sorumluluğunu taşıyabilmesini öneren özerklik kavramı (Gillon, 1995: 60) kişinin kendisini yönetmesini ve kişinin kendi tarafından yapılan öz düzenlemeyi ifade etmektedir (Ryan ve Deci, 2006). Bir diğer tanımda Tolay vd. (2012: 452) özerkliği, çalışanların işlerini nasıl yapacakları konusunda karar verme özgürlüklerini ve işleri üzerinde kontrol sahibi olmaları şeklinde tanımlamaktadır. Özerklik kavramını mesleki özerklik bakış açısından ele alan Meiksins ve Watson (1989) bir eylemi ya da eylemler dizisini başlatma ve sonuçlandırma, yapılacak işin kapsamını, yöntemini ve hızını kontrol edebilme kabiliyeti olarak tanımlamaktadır. Daha açık bir ifadeyle Meiksins ve Watson özerklikte bireyin bir iş ya da olayı başlatabilme kabiliyetinin yanı sıra onun içeriğine, uygulanacak yöntemin tercihine ve işleyiş sürecine müdahale etme yetkisinin bulunması gerektiğini belirtmektedirler (akt. Doğan ve Can, 2009: 134). Etki boyutu ise işgörenlerin örgüt alanı içerisinde stratejik, yönetsel veya operasyonel sonuçlar üzerinde etkilerinin olup olmadığı yönündeki algılarını ifade etmekte (Tolay vd., 2012: 452) ve bireyin kendi iş çevresi üzerinde kontrol ve etkinliğinin olduğu duygusunu vermesi bakımından önemli hale gelmektedir. Bu temel güdünün altında yatan ana neden, geniş bir kısımda kontrol sahibi olma isteğidir. Sahiplik ve bu durumun sağladığı haklar, kişilerin çevrelerini keşfetme ve değiştirmelerine izin verir. Bu şekilde kişiler, doğalarındaki başarılı olma intiyacından dolayı tatmin olmaktadırlar. Kişinin kontrol veya eylemleri sonucunda istenilen çıktılar elde edildikç memnuniyet ve dışsal bir tatmin oluşmaktadır. (Pierce vd. 2001: 300). Etki ayrıca bireyin davranışlarına bağı olarak işinde bir fark yaratabileceğine ilişkin algısını da ifade ederken (Ergeneli ve Arı, 2005: 130); çalışanların işyerlerinde bir iz bırakabilme ve örgütün onların fikirlerini ciddiye alma düzeyini göstermektedir (Tolay vd., 2012: 452).
Karar algısı kavramı işgörenin kararlar ve süreçler üzerindeki etkinliği içeren bir kavramdır. Nitekim bu araştırma içerisinde kontrol algısı kavramı karar kontrolü ve süreç kontrolü boyutlarından oluşmaktadır. Karar kontrol çalışanın yapmış olduğu işin yönünü tayin etme ve çıktıları üzerindeki direkt etkisi olarak tanımlanırken, süreç kontrol ise çıktılar üzerindeki dolaylı etkiyi içermektedir (Miller, 1989: 338). Illgili yazın incelendiğinde bu boyutların örgütsel adalet ve iş zenginleştirme kavramıyla ele alındığı görülmektedir (Miller, 1989; Giacobbe-Miller, 1995; Tyler, 1989; Brashear vd., 2005). Ayrıca psikolojik sahiplenme yazını içerisinde kontrol, sahiplenme olgusunun temel öğelerinden biri olarak değerlendirilmektedir.

\section{3. Özerklik ve Etki ile Psikolojik Sahiplenme ilişkisinde Kontrol Algısının Aracılık Rolü}

Pierce vd. (2003: 18) göre sahiplenme psikolojisinin temelinde hedef nesneyi kontrol, kontrole bağlı olarak yakından tanıma ve benlikle bütünleştirme yatmaktadır. Ayrıcı Pierce vd.'nin (2001) kuramsal bağlamda gerçekleştirmiş oldukları çalışmada hedef nesne üzerindeki kontrolün psikolojik sahiplenmenin oluşumunu sağlayan temel mekanizmalardan biri olduğu belirtilmektedir. Lee ve Chen (2011), psikolojik sahiplenmenin oluşumunda algıların önemli bir yeri olduğunu belirtirken, yapmış oldukları ampirik çalışma sonucunda bireyin nesne üzerinde algılamış olduğu kontrolün, psikolojik sahiplenmenin oluşumuna etkisi olduğunu bulgulamışlardır. Bu sonuca paralel bir şekilde, psikolojik sahiplenmeyi ortaya çıkaran mekanizmaları araştırdıklarını belirten Lee ve Chen (2011), algılanan kontrolün psikolojik sahiplenmenin öncülü oluğunu sonucuna ulaşmıştır. Pierce vd. (2004) çalışmalarında kontrol ve katılımcı karar vermenin psikolojik sahiplenme üzerinde etkili olduğunu belirtmektedirler. Farklı bir çalışmada O'Driscoll vd. (2006: 389), daha az yapılandırılmış iş çevrelerinin işgörene daha fazla kontrol tanıdığından hareketle, yapılandırılmamış iç çevresinin çalışanların örgüt ve işlerine yönelik daha fazla psikolojik sahiplenme sağladığını belirtmektedirler. Kontrol değişkeni ile ilgili olarak Giacobbe Miller (1995: 121) yapmış oldukları çalışmada karar kontrolünün süreç kontrol üzerinde etkisi olduğunu bulgulamıştır.

Araştırmalarında psikolojik sahiplenme teorisini Hackman ve Oldham (1975) tarafından ele alınan Iş Karakteristikleri Modeli'ne doğru genişlettikleri görülen Pierce vd. (2009: 478) göre karmaşık iş yapıları çalışana daha özerk bir alan sunmakta ve onlara işlerini ve iş çevrelerini kendilerine göre dizayn etme fırsatı 
sağlamaktadır. Bu yapılar içerisinde bireyler hedef nesne üzerinde, özerkliğe bağlı olarak kontrol hakkı elde etmektedirler. Üst kısımda açıklanan kontrol algısı ve psikolojik sahiplenme arasındaki kuramsal bağa dayalı olarak, bireye özerklik sağlayan örgüt yapı özellikleri ve iş çevresi yapılarının psikolojik sahiplenmeye pozitif etki yaptığı sonucuna ulaşılabilir. Nitekim O'Driscoll vd. (2006: 409) bireye daha fazla özerklik sağlayan ve katılımcı karar vermenin yüksek olduğu yapılarda, işgörenlerin daha fazla kontrol hissederek işe ve örgüte yönelik psikolojik sahiplenme hissetmelerinin olası olduğunu belirtmektedirler.

Kaur vd. (2013: 3195) göre psikolojik sahiplenme, doğası gereği içsel olarak çevreyi etkileme intiyacı ve kontrol etme isteğiyle yakın ilişkili olan bir kavramdır. Çevreyi değiştirmede nedensel etkililiği yaşama arzusu, sahip olma girişimlerine ve sahiplik hislerinin ortaya çıkmasına neden olmaktadır (Pierce vd. 2001: 300). Bireylerin etkililik hissetme isteği, onların belirli görev, süreç ve işleme yönelik psikolojik sahiplenme hissetmelerine yol açmaktadır (Avey vd., 2009: 177). Hedef nesne üzerindeki kontrolü, etkililik ve öz benlik güdüleriyle ilişkilendiren Pierce vd. (2001) hedef nesne üzerindeki kontrolün o nesneye karşı sahiplenme hissinin gelişmesinde önemli bir araç olduğunu belirtmektedir (Pierce vd., 2001: 301; Pierce vd., 2003: 14).

Özerklik ve etki değişkenlerinin psikolojik sahiplenme üzerine etkisini ve bu etkide kontrol algısının (karar kontrol, süreç kontrol) aracılık etkisini belirlemeye yönelik olan bu araştırmada, Baron ve Kenny (1986: 1176-1177) tarafından önerilen üç koşula bakılmıştır. Birinci koşul, bağımsız değişkenin aracı değişkeni etkilemesi gereklidir. İkinci koşul, bağımsız değişkenlerin bağımlı değişken üzerinde üzerinde etkisi olmalıdır. Üçüncü koşul ise aracı değişkenin bağımlı değişkeni etkilemesidir. Bu koşullardan hareketle, yukarıdaki kuramsal açıklamalar ışığında aşağıdaki hipotezler geliştirilebilir:

H1: Özerkliğin karar kontrol üzerinde olumlu etkisi vardır.

H2: Özerkliğin süreç kontrol üzerinde olumlu etkisi vardır.

H3: Özerkliğin psikolojik sahiplenme üzerinde olumlu etkisi vardır.

H4: Etkinin karar kontrol üzerinde olumlu etkisi vardır.

H5: Etkinin süreç kontrol üzerinde olumlu etkisi vardır.

H6: Etkinin psikolojik sahiplenme üzerinde olumlu etkisi vardır.

H7: Karar kontrolün psikolojik sahiplenme üzerinde olumlu etkisi vardır.

H8: Süreç kontrolün psikolojik sahiplenme üzerinde olumlu etkisi vardır.

H9: Karar kontrolün süreç kontrol üzerinde olumlu etkisi vardır.

H10: Özerklik ile psikolojik sahiplenme ilişkisinde karar kontrolün aracılık etkisi vardır.

H11: Özerklik ile psikolojik sahiplenme ilişkisinde süreç kontrolün aracılık etkisi vardır.

H12: Etki ile psikolojik sahiplenme ilişkisinde karar kontrolün aracılık etkisi vardır.

H13: Etki ile psikolojik sahiplenme ilişkisinde süreç kontrolün aracılık etkisi vardır. Çalışmanın amacına ve kuramsal bulgulara dayalı olarak Şekil 1'de gösterilen şematik araştırma modeli oluşturulmuştur.

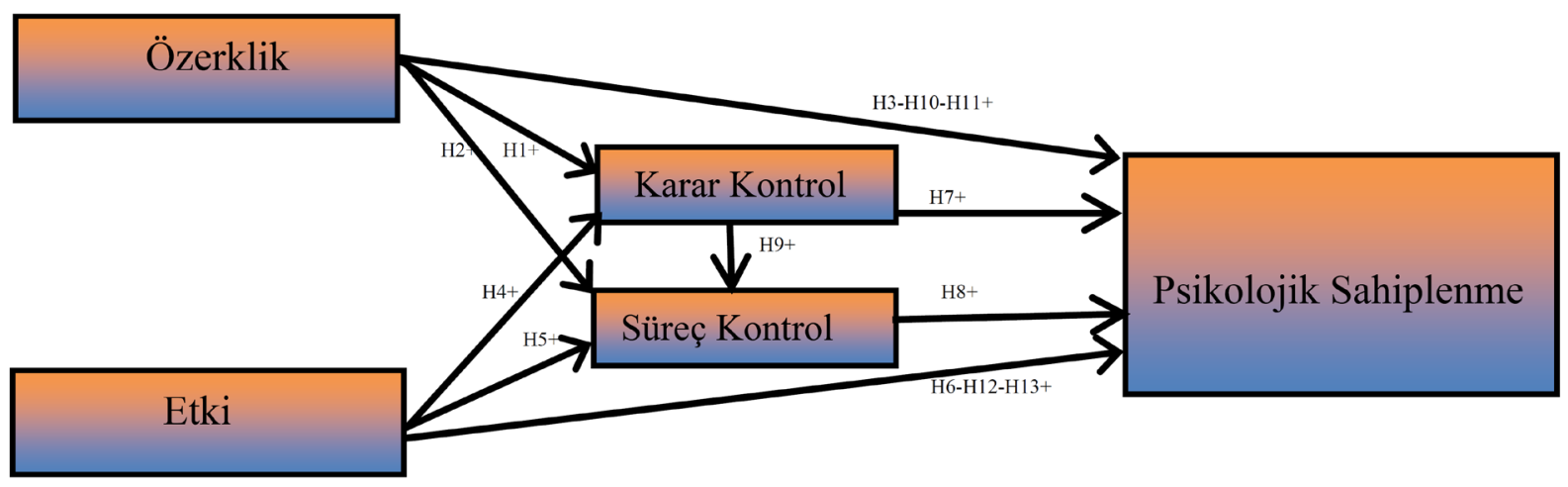

Şekil 1: Araştırma Modeli 


\section{ARAŞTIRMA METEOROLOJISi}

Bu çalışmada ilk olarak örneklem ve ölçeklere ilişkin bilgiler verilmiştir. Daha sonra örneklemden elde edilen verilere dayalı olarak oluşturulan araştırma modelini test edecek analizler gerçekleştirilmiştir. Bu bağlamda veriler güvenilirlik ve faktör analizine tabi tutulmuş olup, oluşturulan araştırma modeli ve hipotezleri test etmek üzere tanımlayıcı istatistikler (ortalama, standart sapma), korelasyon analizi, doğrulayıcı faktör analizi ve yapısal eşitliklerin çözümlenmesi için path (yol) analizi uygulanmıştır. Bu analizlerin uygulanmasında SPSS 21 ve Amos 24 paket programlarından yararlanılmıştır.

\subsection{Araştırma Örneklemi}

Araştırmanın örneklem çerçevesini Bitlis ili ve Bitlis iline bağı ıatvan ilçesinde bankacılık sektöründe görevli 158 katılımcı oluşturmaktadır. Örnekleme türü olarak kolayda örnekleme yöntemi tercih edilmiştir. Katılımcıların büyük bölümünün (\%78.5) erkek oldukları ve ağırlıklı olarak lisans $(\% 54,5)$ derecesine sahip kişilerden oluştukları anlaşılmaktadır. Ayrıca katılımcıların \% 46.2'si 30 yaşın altında genç çalışanlardan \%43,8'inin ise orta yaş grubuna dâhil oldukları görülmektedir. Diğer taraftan, katıımcıların çoğunluğunun $(\% 67,7) 5$ yıldan daha az bir süredir kurumlarında çalıştıkları önemli bir bulgu olarak belirtilebilir.

\subsection{Araştırma Ölçekleri}

Nesnelci yaklaşımla tasarımlanan bu araştırmada anket yöntemi tercih edilmiştir. Analize konu olacak araştırma verilerinin elde edilmesi için yapılandırılmış soru formu kullanılmıştır. Soru formu, toplam 32 maddeden oluşmaktadır. Bu maddelerin 25'i araştırmaya konu olan değişkenleri temsil eden ölçeklere ilişkin iken geri kalan 7 madde ise katılımcıların demografik özelliklerini belirlemek üzere hazırlanmıştır. Araştırma değişkenlerinden özerklik ve etki değişkenlerini ölçmek üzere Spreitzer (1995) tarafından geliştirilen psikolojik güçlendirme (psychological emperwoment) ölçeğine ait özerklik ve etki boyutlarından yararlanılmıştır. Kontrol değişkenini ölçmek için Brasher vd. (2005) tarafından, Tylor (1989) ve Giacobbe ve Miller (1995)'in çalışmalarına dayalı olarak geliştirilen ve güvenilirlik ve geçerliği Turunç ve Çelik'in (2010: 170-171) çalışmalarında test edilmiş olan iki boyutlu kontrol algısı (karar kontrol ve süreç kontrol) ölçeğin- den yararlanılmıştır. Psikolojik sahiplenmeyi ölçmek için ise Van Dyne ve Pierce (2004) tarafından geliştirilen, güvenilirlik ve geçerliliği Ötken'in (2015: 125) çalışmasında test edilmiş olan tek boyutlu ölçekten yararlanılmıştır. Güvenilirlik analizi sonuçlarına göre, kontrol değişkeninin süreç kontrolü ve karar kontrolü boyutlarına ilişkin Cronbach Alfa değerleri sırasıyla $a=, 850$ ve $a=, 870$, pisikolojik güçlendirme ölçeğinin boyutları içerisinde yer alan özerklik ve etki boyutlarına ait Cronbach Alfa değerlerinin sırasıyla $a=, 880$ ve $a=, 930$ ve tek boyutlu psikolojik sahiplenme değişkenine ait Cronbach Alfa değerinin ise $a=, 908$ olduğu görülmüştür. Bu sonuçlar değişkenlerin maddeleri arasında iç tutarlılığın olduğunu göstermektedir.

Kontrol Algısı ölçek maddeleri faktör analizi sonucunda 2 boyutlu, özerlik ve etki boyutları kendi aralarında 2 boyutlu bir yapı ve son olarak psikolojik sahiplenme ise tek boyutlu oldukları belirlenmiştir.

Faktör analizi sonuçlarına göre özerklik boyutu açıklayan maddelerin faktör yükleri ,822-,825 aralığında, Etki boyutunu ,853-,917 aralığında, süreç kontrol boyutunun ,810-,844 arasında, karar kontrol boyutunun ,634-,841 aralığında ve son olarak psikolojik sahiplenme değişkenini açıklayan maddelerin ise ,827-,937 aralığında değiştiği izlenmiştir. Karar kontrolü ve süreç kontrolü boyutlarından oluşan kontrol algısı değişkeninin KMO değeri ,866 olarak tespit edilmiş ve Bartlett test değeri $(705,890)$ $\mathrm{p}=, 000<, 05$ önem düzeyinde anlamlıdır. Toplam varyansı açıklama yüzdesi ise \%70,499'dur. Kendi içerisinde iki boyutlu bir yapı oluşturan özerklik ve etki boyutlarının oluşturmuş olduğu değişkenin faktör analizi sonucunun KMO değeri ,821 olarak tespit edilmiş ve Bartlett test değeri $(84,495) \mathrm{p}=.000<, 05$ önem düzeyinde anlamlıdır. Toplam varyansı açıklama yüzdesi ise $\% 81,471$ 'dir. Psikolojik sahiplenme değişkeninin faktör analizi sonucuna göre KMO değeri ,821 olarak tespit edilmiş ve Bartlett test değeri $(932,480) \mathrm{p}=, 000<, 05$ önem düzeyinde anlamlıdır. Toplam varyansı açıklama yüzdesi $\% 81,475^{\prime}$ tir.

Yapılan temel bileşenler analizleri sonucunda elde edilen faktör yapıları doğrulayıcı faktör analizi (DFA) sonuçlarıyla karşılaştııılmış ve temel bileşen analizi sonucunda elde edilen faktör yapılarını desteklediği görülmüştür. Tablo 1'de doğrulayıcı faktör analizi sonucunda ulaşılan ölçeklerin uyum iyiliği değerleri görülebilmektedir. 
Tablo 1: Doğrulayıcı Faktör Analizi Uyum İyiliği Değerleri

\begin{tabular}{|l|c|c|c|c|c|c|c|}
\hline DEĞişKENLER & $\begin{array}{c}\text { CMIN/DF } \\
<\mathbf{5}\end{array}$ & $\begin{array}{c}\text { GFI } \\
>\mathbf{8 5 0}\end{array}$ & $\begin{array}{c}\text { AGFI } \\
\mathbf{7 . 8 0 0}\end{array}$ & $\begin{array}{c}\text { CFI } \\
\mathbf{7 . 9 0 0}\end{array}$ & $\begin{array}{c}\text { NFI } \\
>\mathbf{. 9 0 0}\end{array}$ & $\begin{array}{c}\text { TLI } \\
>\mathbf{. 9 0 0}\end{array}$ & $\begin{array}{c}\text { RMSEA } \\
<.080\end{array}$ \\
\hline Süreç Kontrol & 1,710 & .895 & .879 & .914 & .921 & .928 & .071 \\
\hline Karar Kontrol & 1,637 & .940 & .959 & .981 & .999 & .979 & .65 \\
\hline Özerklik & 1,293 & .910 & .900 & .962 & .937 & .949 & .054 \\
\hline Etki & 1,618 & .903 & .923 & .936 & .941 & .914 & .061 \\
\hline Psikolojik Sahiplenme & 1,547 & .995 & 951 & .999 & .997 & .993 & .059 \\
\hline
\end{tabular}

\section{BULGULAR}

Bu aşamada ilk olarak tanımlayıcı istatistikler (standart sapma, ortalama) ve korelasyon analizleri yapılmıştır.

Tablo 2: Verilere ilişkin Ortalama, Standart Sapma ve Korelasyon Değerleri

\begin{tabular}{|l|c|c|c|c|c|c|c|}
\hline & Ort. & SS. & $\mathbf{1}$ & $\mathbf{2}$ & $\mathbf{3}$ & $\mathbf{4}$ & $\mathbf{5}$ \\
\hline Özerklik & 3,4662 &, 95914 & $(, 880)$ & & & & \\
\hline Etki & 3,4051 &, 95128 &, $562^{* *}$ & $(, 930)$ & & & \\
\hline S.Kontrol & 3,7152 &, 87735 &, $499^{* *}$ &, $455^{* *}$ & $(, 850)$ & & \\
\hline K.Kontrol & 3,4937 &, 83450 &, $485^{* *}$ &, $564^{* *}$ &, $635^{* *}$ & $(, 870)$ & \\
\hline Pisikolojik Sahiplenme & 3,9734 &, 90268 &, $383^{* *}$ &, $318^{* *}$ &, $510^{* *}$ &, $544^{* *}$ & $(, 908)$ \\
\hline
\end{tabular}

Not: Parantez içindeki rakamlar Cronbach Alfa değerini göstermektedir.

Tablo 2'de de görüldüğü gibi araştırma konusu tüm bağımlı ve bağımsız değişkenler arasında anlamlı etkiler bulunmaktadır. Dolayısıyla değişkenler arasında önemli etkiler öngörülebilmektedir.

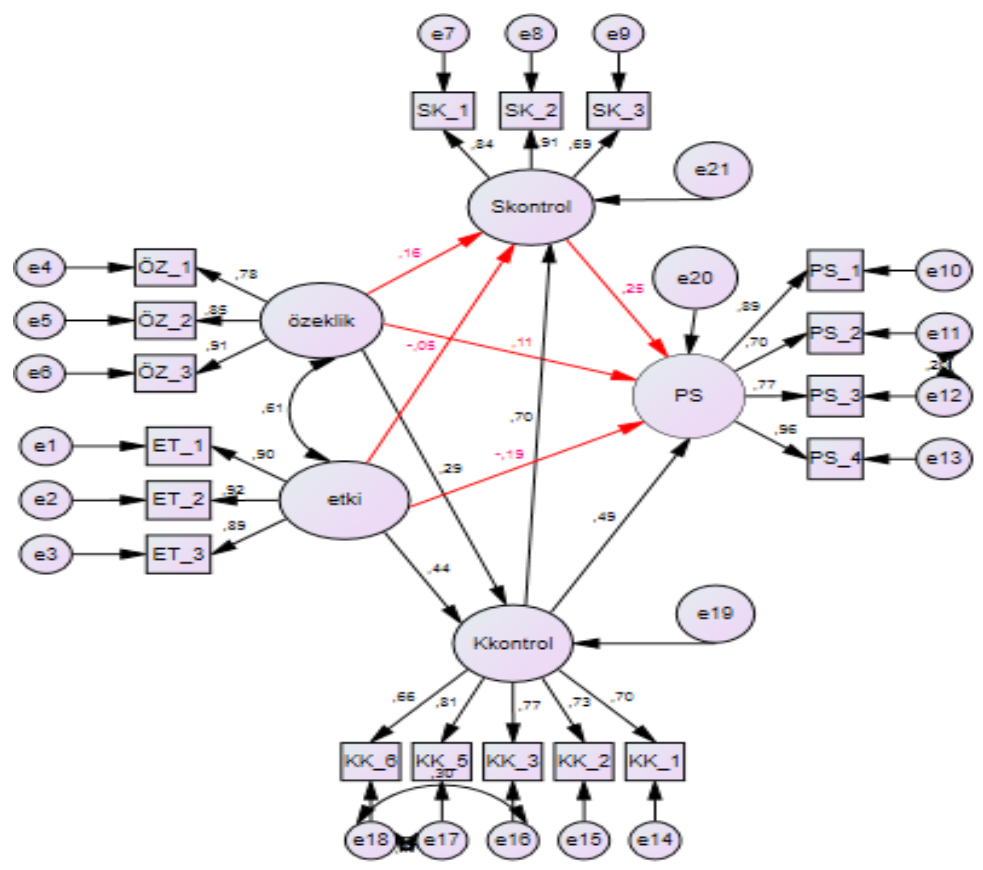

Şekil 2: Tam aracılık Yapısal Eşitlik Modeli 1 (YEM) Standardize Beta Katsayı Değerleri 
Tablo 3: Regresyon ve anlamlılık

\begin{tabular}{|l|l|l|c|c|}
\hline Regresyon & & & Estimate & $\mathbf{P}$ \\
\hline Etki & $\rightarrow$ & Kkontrol &, 361 & $* * *$ \\
\hline Özerklik & $\rightarrow$ & Kkontrol &, 214 &, 004 \\
\hline Özerklik & $\rightarrow$ & Skontrol &, 151 &, 084 \\
\hline Kkontrol & $\rightarrow$ & Skontrol &, 893 & $* * *$ \\
\hline Etki & $\rightarrow$ & Skontrol &,- 055 &, 593 \\
\hline Özeklik & $\rightarrow$ & PS &, 106 &, 281 \\
\hline Kkontrol & $\rightarrow$ & PS &, 659 &, 002 \\
\hline Etki & $\rightarrow$ & PS &,- 204 &, 076 \\
\hline Skontrol & $\rightarrow$ & PS &, 268 &, 051 \\
\hline
\end{tabular}

Araştırma amacı doğrultusunda Şekil 1'de varsayılmanmış olan yapısal eşitlik modelini test etmek üzere modele path analizi uygulanmıştır. Analiz sonuçları Şekil 2 üzerinden gözlenebilir. Ayrıca Tablo 4'te modele ait uyum iyiliği değerleri görülebilmektedir.

Temel yapısal eşitlik modeli üzerinde yapılan ilk analiz sonucunda NFI dışında bütün uyum iyiliği değerlerinin kabul edilebilir sınır içerisinde olduğu görülmüştür. NFI uyum iyiliği değerini kabul edilebilir sınırlar içerisine çekebilecek değişiklikleri yapmak için model 1 analiz çıktıları kısmında programın önermiş olduğu modifikasyonlar incelenmiş ve ki-kare üzerinde en yüksek değişikliği ortaya çıkaracak hata ter- imleri arasında oluşturulması gereken kovaryanslar sırasıyla oluşturulmuştur. Yeniden yapılan analizler sonucunda modelin veriye iyi bir şekilde uyduğu Tablo 4'te verilen uyum iyiliği değerlerinden anlaşımaktadır. Bununla birlikte yeni bağlantıların modeli anlamlı bir şekilde geliştirip geliştirmediği ki-kare fark istatistiğinden (Bayram, 2013:117) bakılmış ve oluşturulan kovaryansların modeli anlamlı bir şekilde geliştirdiği görülmüştür.

YEM 1'de değişkenler arasında çizilen regresyon katsayıları incelendiğinde Etki'nin Karar Kontrolü ve Süreç Kontrolü üzerinde, Özerkliğin Psikolojik sahiplenme ve Süreç Kontrolü üzerinde ve son olarak Süreç Kontrolün Psikolojik Sahiplenme üzerinde istatistiksel olarak anlamlı bir etkisinin olmadığı görülmektedir. Buna karşın Özerkliğin Karar kontrolü üzerinde, Karar Kontrolün Süreç Kontrolü ve PS üzerinde, Etki'nin de PS üzerinde istatistiksel olarak anlamlı bir etkisinin olduğu izlenmektedir. Dolayısıyla Süreç Kontrolün eksojen (bağımsız) değişkenler tarafından yordanmadığı anlaşılmaktadır. Bu çalışmada temel olarak kontrolün aracılık rolü araştırıldığından süreç kontrol modelden çıkarılıp yeniden analiz yapılması gerekmektedir (Şimşek, 2007:146; Meydan ve Şeşen 2015. 128).

Tablo 4: YEM 1 Analizi Uyum İyiliği Değerleri

\begin{tabular}{|c|c|c|c|c|c|c|c|}
\hline MODEL & CMIN/DF & GFI & AGFI & CFI & NFI & TLI & RMSEA \\
$<\mathbf{2}$ & $>\mathbf{8 5 0}$ & $>\mathbf{8 0 0}$ & $>.900$ & $>.900$ & $>.900$ & $<0$ \\
\hline YEM 1 & 1,694 & .880 & .834 & .958 & .905 & .948 & .066 \\
\hline
\end{tabular}

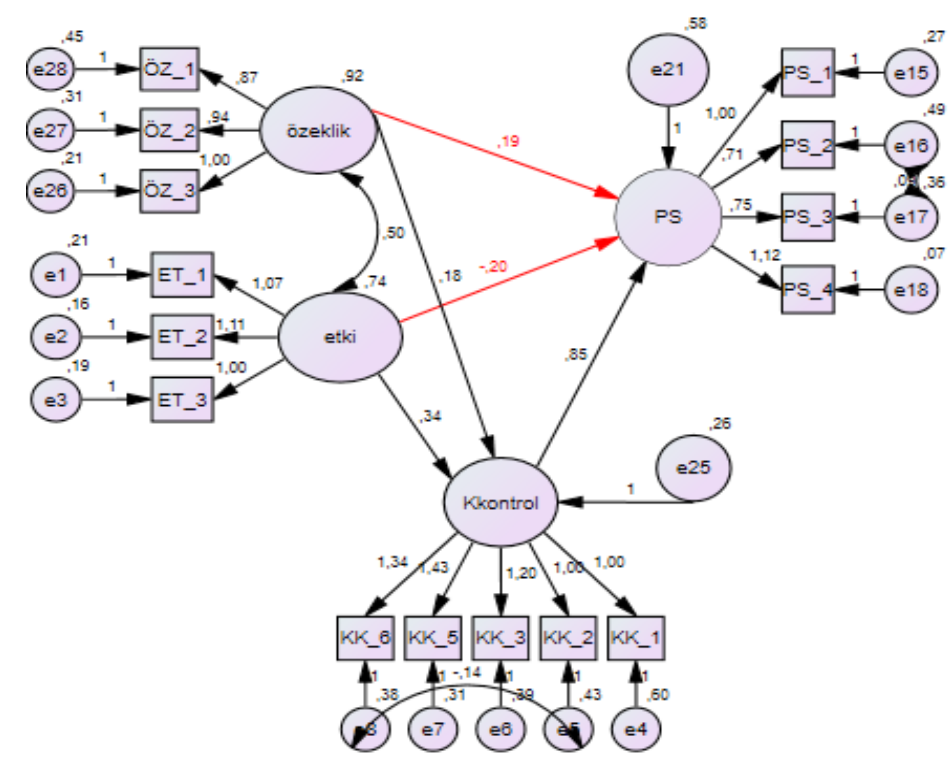

Şekil 3: Tam aracılık YEM 2 Standardize Beta Katsayı Değerleri 
Tablo 5'te yer alan YEM 2 uyum iyiliği değerlerinin modeli doğruladığı anlaşılmaktadır. Ancak model 2 üzerinde yer alan karar kontrolü ve psikolojik sahiplenme değişkenleri üzerinde birer modifikasyon yapılmıştır. Yapılan modifikasyonların modeli anlamlı bir şekilde geliştirip geliştirmediği ki-kare fark istatistiğinden bakılmış ve modifikasyonların modeli anlamlı bir şekilde geliştirdiği görülmüştür. Model 2'de özerklik ve etkinin karar kontrolü $\mathrm{p}=, 000<0,001$ anlamlılık düzeyinde yordadığı, karar kontrolünde psikolojik sahiplenmeyi $p=, 000<0,001$ anlamlılık düzeyinde yordadığı bulgulanmıştır. Buna karşın özerklik ile psikolojik sahiplenme ve etki ile psikolojik sahiplenme arasında anlamlı bir ilişki bulunamamıştır. Bu durum karar kontrolün özerklik ve psikolojik sahiplenme arasında ve ayrıca etki ile psikolojik sahiplenme arasında tam aracilık etkisinin olabileceğine işaret etmektedir. Ancak tam aracilıktan bahsedebilmek için Baron ve Kenny'nin (1986) ikinci şartının (Bağımsız değişkenin bağımlı değişken üzerinde etkisi olmalıdır.) doğrulanması gerekmektedir. Bu amaçla özerlik-karar kontrolü ve özerklik-psikolojik sahiplenme arasında oluşturulacak regresyon modelinin test edilmesi gerekmektedir. Bunun için sırasıyla iki ayrı yapısal eşitlik regresyon modeli oluşturulmuş ve analizler yapılmıştır.

Tablo 5'te yer alan uyum iyiliği değerleri incelendiğinde Regresyon modeli 1'in uyum iyiliği değerleri modeli doğrularken, Regresyon modeli 2'nin RMSEA değerinin olması gereken sınırdan çok yüksek olduğu görülmüş ve model doğrulanamamıştır. Dolayısıyla özerkliğin psikolojik sahipliği etkilediği doğrulanırken, etkinin psikolojik sahiplenmeyi yordamadığı anlaşılmaktadır. Bununla birlikte aracı değişkenin ve bağımlı değişken üzerindeki etkisi (Baron ve Kenny'nin (1986) 3. Şartı) model 1'de doğrulandığından bunun için farklı bir yapısal eşitlik modeli sınanmamıştır. Son durumda karar kontrol değişkeninin tam aracılık rolünü ispatlamak için model 2'den etki değişkeni çıkarılarak oluşturulan model yeniden test edilmiştir.

Tablo 5: YEM 2 Analizi Uyum İyiliği Değerleri

\begin{tabular}{|l|c|c|c|c|c|c|c|}
\hline DEĞişKENLER & $\begin{array}{c}\text { CMIN/DF } \\
<\mathbf{5}\end{array}$ & $\begin{array}{c}\text { GFI } \\
>.850\end{array}$ & $\begin{array}{c}\text { AGFI } \\
>.800\end{array}$ & $\begin{array}{c}\text { CFI } \\
>.900\end{array}$ & $\begin{array}{c}\text { NFI } \\
>.900\end{array}$ & $\begin{array}{c}\text { TLI } \\
>.900\end{array}$ & $\begin{array}{c}\text { RMSEA } \\
<.080\end{array}$ \\
\hline YEM 2 & 1,497 & 897 & .849 & .962 & .919 & .951 & .071 \\
\hline
\end{tabular}

Tablo 6: YEM 1 Analizi Uyum İyiliği Değerleri

\begin{tabular}{|l|c|c|c|c|c|c|c|}
\hline DEĞişKENLER & $\begin{array}{c}\text { CMIN/DF } \\
<\mathbf{5}\end{array}$ & $\begin{array}{c}\text { GFI } \\
>\mathbf{8 5 0}\end{array}$ & $\begin{array}{c}\text { AGFI } \\
>\mathbf{8 0 0}\end{array}$ & $\begin{array}{c}\text { CFI } \\
>\mathbf{. 9 0 0}\end{array}$ & $\begin{array}{c}\text { NFI } \\
\mathbf{7 . 9 0 0}\end{array}$ & $\begin{array}{c}\text { TLI } \\
>\mathbf{. 9 0 0}\end{array}$ & $\begin{array}{c}\text { RMSEA } \\
<. \mathbf{0 8 0}\end{array}$ \\
\hline Regresyon 1 & 1,516 & .966 & .927 & .991 & .973 & .985 & .057 \\
\hline Regresyon 2 & 3,200 & .956 & .859 & .969 & .956 & .946 & 112 \\
\hline
\end{tabular}

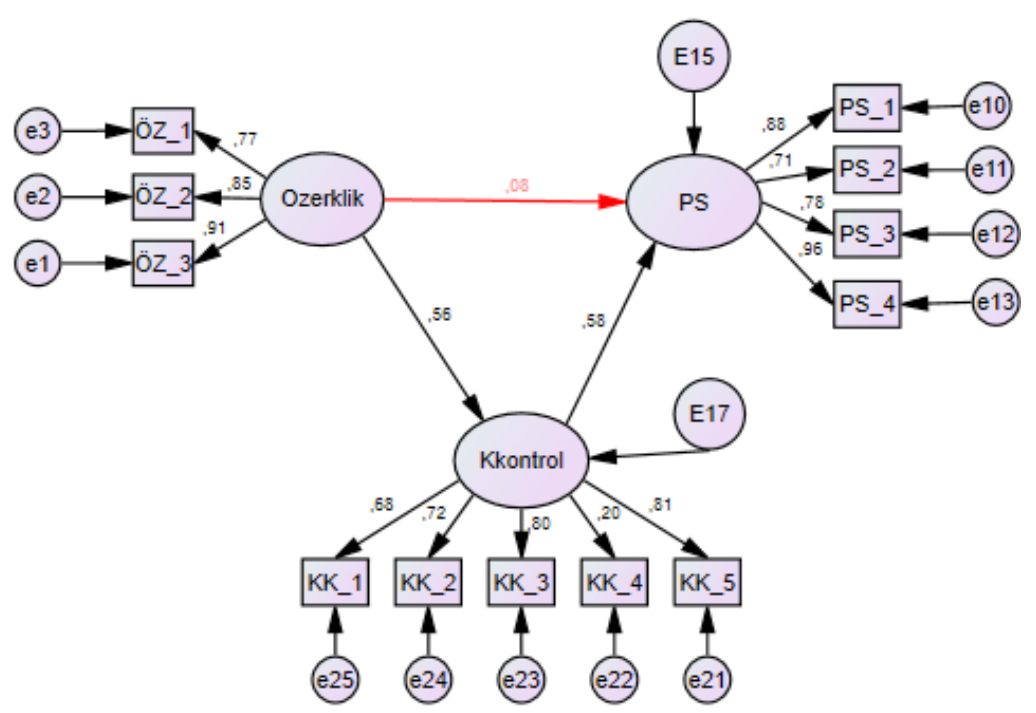

Şekil 4: Tam Aracılık YEM 5 Standardize Beta Katsayı Değerleri 
Tablo 7: Regresyon ve anlamlılık

\begin{tabular}{|l|c|c|c|c|}
\hline Regresyon & & & Estimate & P \\
\hline Özeklik & $\rightarrow$ & PS &, 076 & $* 07$ \\
\hline Özerklik & $\rightarrow$ & Kkontrol &, 510 & $* * *$ \\
\hline Kkontrolü & $\rightarrow$ & PS &, 626 & $* * *$ \\
\hline
\end{tabular}

Tablo 8: YEM 1 Analizi Uyum İyiliği Değerleri

\begin{tabular}{|c|c|c|c|c|c|c|c|}
\hline MODEL & $\begin{array}{c}\text { CMIN/DF } \\
<\mathbf{5}\end{array}$ & $\begin{array}{c}\text { GFI } \\
>.850\end{array}$ & $\begin{array}{c}\text { AGFI } \\
>.800\end{array}$ & $\begin{array}{c}\text { CFI } \\
>.900\end{array}$ & $\begin{array}{c}\text { NFI } \\
>.900\end{array}$ & $\begin{array}{c}\text { TLI } \\
>.900\end{array}$ & $\begin{array}{c}\text { RMSEA } \\
<.080\end{array}$ \\
\hline YEM 5 & 1,307 & .938 & .906 & .985 & .940 & .981 & .044 \\
\hline
\end{tabular}

Modelin uyum iyiliği değerleri Tablo 8'da verilmektedir. Uyum iyiliği değerlerinin çok yüksek olduğu ve modelin anlamlı olduğu gözlenmektedir, dolayısıyla özerklik ve psikolojik sahiplenme arasında karar kontrolün tam aracılık etkisi olduğu bulgulamıştır.

\section{SONUÇ}

Bu çalışmada algılanan özerklik ve etki ile psikolojik sahiplenme ilişkisinde kontrol algısının aracılık etkisinin ortaya konması amaçlanmıştır. Verilerin analizi sonucunda, özerklik ile psikolojik sahiplenme ilişkisinde karar kontrolü boyutunun tam aracılık rolü olduğu bulgulanmıştır. Özerklik, işgörenlerin işleriyle ilgili insiyatif alabilme ve bunun sorumluluğunu taşıyabilmesini ifade etmektedir. Diğer bir ifadeyle kişinin işi üzerindeki özerklik algısı kontrol algısına neden olduğundan PS'nin oluşmasını sağlamaktadır. Öte yandan, özerklik algısının süreç kontrolü üzerinde, süreç kontrolünde psikolojik sahiplenme üzerinde anlamlı bir etkisinin olmadığı görülmüştür. Bu sonuç işgörenlerin işleri ve örgütleri üzerinde almış oldukları insiyatif ve sorumlulukların direkt etkilerini açılayan özerklik ve örgütsel süreç ve çıktılar üzerindeki dolaylı etkilerini açıklayan süreç kontrolü arasında bir ilişkinin olmadığı anlamına gelmektedir.

Etki değişkeni ile süreç kontrolü ve psikolojik sahiplenme arasında doğrudan bir ilişki bulgulanamamıştır. Ancak etki boyutunun karar kontrol üzerinde olumlu etkisi olduğu görülmektedir. Özellikle de etki ve psikolojik sahiplenme arasında doğrudan bir ilişkinin olmaması, dolaylı etkilerin PS oluşumunda herhangi bir açıklayıcılığının olmadığını ortaya koymaktadır. Ancak etki boyutunun karar kontrolü üzerinde pozitif etkisinin olması dikkate değerdir. Bu sonuçlar genel olarak değerlendirildiğinde dolaylı etkilerden ziyade direkt etkilerin yani nesne üzerinde bireyin özerkliğine bağlı olarak elde etmiş olduğu direkt kontrolün PS oluşmasına katkı sağladığı anlaşımaktadır. Ancak dolaylı etkilerin (etki) direkt etkileri (karar kontrol) olumlu yönde etkilemesine karşın PS oluşumunda yetersiz kaldığı anlaşılmıştır. Nitekim yazında bu sonucu destekleyecek açıklamaların olduğu görülmektedir. Örneğin, Rudmin ve Berry (1987) sahiplenme hissinin esas olarak nesneleri kontrol edebilme ve kullanabilme anlamına geldiğini belirtmektedir (Pierce vd, 2001; 301). Bir diğer araştırmada Pierce vd. $(2003: 14,15)$ kontrol edilebilen nesnelerin benliğin bir parçasıymış gibi görüldüğünü ve bu durumun psikolojik sahiplenmeyi ortaya çıkardığını, diğer taraftan kontrol edilemeyen veya diğerleri tarafından kontrol edilen nesneler ise benlikle bütünleştirilemediği için psikolojik sahiplenme oluşumunu sağlayamamaktadır.

Süreç kontrol ve psikolojik sahiplenme arasında da herhangi bir ilişki bulgulanamamıştır. Nitekim Miller (1989) süreç kontrolü tanımı (bireyin süreçler ve çıktılar üzerindeki dolaylı etkisi) dikkate alındığında bu bulguya anlamlı bir açıklama getirilebileceği de anlaşılmaktadır. Dolayısıyla birey direkt kontrolünün bulunduğu nesnelere karşı sahiplenme hissederken, üzerinde dolaylı yollardan kontrolünün olduğu nesnelere karşı sahiplenme hissetmemektedir.

Bu araştırma sonuçlarının örgütler ve uygulayıcılar açısından önemli olduğu değerlendirilmektedir. Yüksek düzeyde olumlu tutum ve davranışlarla ilişkilendirilen psikolojik sahiplenme olgusunun örgütlerin etkinliği ve verimliliği üzerindeki etkisi kaçınılmazdır. $\mathrm{Bu}$ bakımdan insan kaynakları yöneticilerinin ve iş dizaynı hazırlayan yönetici ya da uygulayıcıların işgörenin özerk davranabildiği ve direkt kontrolünü esas alacak temel iş bölümleri inşa etmeleri psikolojik sahiplenme hissinin gelişmesi açısından önemlidir.

Ancak tüm bu sonuçlarla birlikte bu çalışmanın örneklem çerçevesinde değerlendirilmelidir. Araştır- 
ma Örneklemi Bitlis ili ve Tatvan ilçesinde kamu ve özel banka çalışanlarıyla sınırlandırıımıştır. Her ne kadar araştırma örneklemine dâhil edilen toplam kişi sayısı düşük gözükse de Bitlis ili ve Tatvan ilçesinde toplam banka çalışanı sayısının 230 u geçmediği düşünüldüğünde, neredeyse ana kütlenin $2 / 3$ 'nin örnekleme dâhil edildiği anlaşılmaktadır. Ayrıca, bu çalışmada psikolojik sahiplenmeyi ortaya çıkaran etki ve özerklik değişkenleri üzerine odaklanılmıştır. Bu araştırmadaki bir diğer sınırlıık ise kontrol algısı değişkeninin etki ve özerlik ile psikolojik sahiplenme arasında aracı değişken olarak ele alınmasıdır. Ancak insan doğasının karmaşıklığı düşünüldüğün de daha farklı olgularında psikolojik sahiplenmeye etki edeceği aşikârdır. Bu nedenle araştırmacıların farklı örgütsel yapı ve özellikler, hedef nesneye yapılan yatırım, hedef nesnenin çekiciliği ve bir kısım bireysel özellikleri bağımsız değişken olarak, benlik algısı, bir alana sahip olma hissi, sorumluluk hissi ve motivasyon gibi değişkenleri de aracı ya da düzenleyici değişkenler olarak farklı modeller üzerinden psikolojik sahiplenmeye etkisini değerlendirmeleri psikolojik sahiplenme yazının teorileşmesine katkı sağlayacaktır. Ayrıca araştırmacılar tarafından modelin farklı meslek ve daha büyük örneklemlerle test edilmesi genelleme yapılabilmesi bakımından önemlidir.

\section{KAYNAKÇA}

Asatryan, V.S., ve Oh, H. (2008)“Psychological Ownership Theory: An Exploratory Application in The Restaurant Industry", Journal of Hospitality\&TourismResearch, 32: 363-386.

Atalay, C. G. and Özler, D. E. (2013) "A Research to Determine the Relationship between Organizational Justice and Psychological Ownership among Nonfamily Employees in a Family Business", Procedia-Social and Behavioral Sciences, 99, 247-256.

Avey, J. B., Avolio, B. J., Crossley, C. D., ve Luthans, F (2009). "Psychologicalownership: Theoretical Extensions, Measurement and Relation to Work Outcomes", Journal of Organizational Behavior, 30(2), 173-191.

Avey, J. B.,Wernsing, T. S., ve Palanski, M. E. (2012) "Exploringtheprocess of Ethicalleadership: The mediating Role Of Employee Voice and psychological ownership", Journal of Business Ethics, 107(1): 21-34.

Baron RM, ve Kenny D. A. (1986) "The ModeratorMediator Variable Distinction in Social Psychological Research: Conceptual, Strategic, and Statistical Considerations", Journal of Personality and Social Psychology, 51:1173-1182.

Bayram, N. (2013) "Yapısal Eşitlik Modellemesine Giriş Amos Uygulamaları" Ezi Kitapevi: Bursa.

Bernhard, F., ve O'Driscoll, M. P. (2011) "Psychological Ownership in Small Family-Owned Businesses: Leadership Style and Non Family-Employees' Work Attitudes and Behaviors", Group \& Organization Management, 36(3): 345-384.

Brashear, T. G., Manolis, C., ve Brooks, C. M. (2005) “The Effects of Control, Trust, and Justice on Salesperson Turnover", Journal of Business Research, 58(3): 241-249.

Brown, G., Lawrence, T. B., ve Robinson, S. L. (2005) "Territoriality in Organizations", Academy of Management Review, 30(3): 577-594.
Chi, N. W., ve Han, T. S. (2008) "Exploring The Linkages Between Formal Ownership and Psychological Ownership for The Organization: The Mediating Role of Organizational Justice", Journal of OccupationalandOrganizationalPsychology, 81(4): 691-711.

Doğan, H., ve Ali, C. A. N. (2009) “Örgütlerde Mesleki Özerklik Sorunu ve Süleyman Demirel Üniversitesi Sağlık Araştırma ve Uygulama Merkezi'nde Ampirik Bir Çalışma", Çukurova Üniversitesi Sosyal Bilimler Enstitüsü Dergisi, 18(1): 133-148.

Ergeneli, A., ve Arı, G. S. (2005)“Krizde İşten Çıkarılmaların Banka Yöneticileri Üzerine Etkileri: Örgütsel Bağlılık, Güven ve Güçlendirme Algıları", Ankara Üniversitesi SBF Dergisi, 60(01): 121-148.

Etzioni, A. (1991) "The Socio-Economics of Property. In F. W. Rudmin (Ed.), To Have Possessions: A Hand Book on Ownership and Property", Special Issue, Journal of Social Behavior and Personality, 6(6), 465-468.

Florkowski, G. W. (1987) “The Organizational Impact of Profit Sharing", Academy of management Review, 12(4): 622-636.

Ghafoor, A., Qureshi, T. M., Khan, M. A., ve Hijazi, S. T. (2011) "Transformational Leadership, Employee Engagement and Performance: Mediating Effect of Psychological Ownership", Africanjournal of business management, 5(17): 7391-7403.

Giacobbe -Miller, J., (1995) “A Test of The Group Values and Control Models of Procedural Justice From The Competing Perspectives of Labor and Management", Personal Psychology, 48(1):115-42.

Gillon R. (1995), Philosophical Medical Ethics, Wiley Medical, London.

Han, T. S.,Chiang, H. H., ve Chang, A. (2010) “Employee Participation in Decision Making, Psychological 
Ownership and Knowledge Sharing: Mediating Role of Organizational Commitment in Taiwanese HighTechorganizations", The International Journal of Human Resource Management, 21(12): 2218-2233.

Kaur, D., Sambasivan, M., ve Kumar, N. (2013) “Effect of Spiritual İntelligence, Emotional İntelligence, Psychological Ownership and Burnout on Caring Behaviour of Nurses: A Cross-Sectional study", Journal of Clinical Nursing, 22(21-22): 3192-3202.

Lee, Y., ve Chen, A. N. (2011) "Usability Design and psychological Ownership of A Virtual World", Journal of Management Information Systems, 28(3): 269-308.

Liu, J.,Wang, H., Hui, C., ve Lee, C. (2012) “Psychological Ownership: How Having Control Matters", Journal of Management Studies, 49(5): 869-895.

Mayhew, M. G.,Ashkanasy, N. M., Bramble, T., ve Gardner, J. (2007) "A study of the antecedents and consequences of psychological ownership in organizational settings", The Journal of social psychology, 147(5), 477500 .

Meydan, C. H. ve Şeşen, H. (2015) "Yapısal Eşitlik Modellemesi Amos Uygulamaları", Detay Yayıncılık: Ankara.

Miller, M. L., (1989) "Process and Decision Control in the Work Place: Separate Effects, independence From Distributive Justice, and Tests of Explanatory Mechanisms", Basic and Applied Social Psychology, 10(4): 337-354.

O'driscoll, M. P., Pierce, J. L., ve Coghlan, A. M. (2006) "The Psychology of Ownership Work Environment Structure, Organizational Commitment, and Citizenship Behaviors", Group \& Organization Management, 31(3): 388-416.

Olckers, C.,ve DuPlessis, Y. (2012) "Psychological Ownership: A Managerial Construct for Talent Retention and Organisational Effectiveness", African Journal of Business Management, 6(7): 2585-2596.

Ötken, A. B. (2015) "Algılanan Örgütsel Destek ve Psikolojik Sahiplenme Arasındaki İlişki ve Bu İlişkide Örgütsel Adaletin Rolü", Hacettepe Üniversitesi Iktisadi Ve İdari Bilimler Fakültesi Dergisi, 33(2): 113-140.

Özler, H., Yılmaz, A. and Özler, D. (2008) “Psychological Ownership: An Empirical Study on Its Antecedents and Impacts upon Organizational Behaviors", Problems and Perspectives in Management, 6(3), 38-47.

Paré, G., Sicotte, C., ve Jacques, H. (2006) “The Effects of Creating Psychological Ownership on Physicians' Acceptance of Clinical Information Systems" Journal of the American Medical Informatics Association, 13(2): 197-205.
Pierce, J. L., ve Furo, C. A. (1991)“Employee Ownership: Implications for Management", Organizational Dynamics, 18(3): 32-43.

Pierce, J. L.,ve Jussila, I. (2010) “Collective Psychological Ownership Within The Work and Organizational Context: Construct Introduction and Elaboration", Journal of Organizational Behavior, 31(6): 810-834.

Pierce, J. L., ve Rodgers, L. (2004) "The Psychology of Ownership and Worker-Owner Productivity", Group \& Organization Management, 29(5). 588-613.

Pierce, J. L.,Jussila, I., ve Cummings, A. (2009) "Psychological Ownership Within The Job Design Context: Revision of The Job Characteristics Model", Journal of Organizational Behavior, 30(4): 477-496.

Pierce, J. L., Kostova, T., ve Dirks, K. T. (2003) “The State of Psychological Ownership: Integrating and Extending A Century of Research", Review of general psychology, 7(1): 84.

Pierce, J. L.,Kostova, T., ve Dirks, K. T. (2001) "Toward A Theory of Psychological Ownership in Organizations", Academy of Management Review, 26(2): 298-310.

Pierce, J. L.,O'driscoll, M. P., ve Coghlan, A. M. (2004) "Work Environment Structure And Psychological Ownership: The Mediating Effects Of Control", The Journal of Social Psychology, 144(5): 507-534.

Pierce, J. L.,Rubenfeld, S. A., ve Morgan, S. (1991) "Employee Ownership: A Conceptual Model of Process and Effects", Academy of Management Review, 16(1): 121-144.

Ryan, R. M., ve Deci, E. L. (2006) "Self Regulation and the Problem of Human Autonomy: Does Psychology Need Choice, Self Determination, and Will?", Journal of Personality, 74(6): 1557-1586.

Sieger, P.,Zellweger, T., ve Aquino, K. (2013) “Turning Agentsinto Psychological Principals: Aligning Interests of Non Owners through Psychological Ownership", Journal of Management Studies, 50(3): 361-388.

Spreitzer, G. M. (1995) “Psychological Empowerment in the Workplace: Dimensions, Measurement, and Validation", Academy of management Journal, 38(5): 1442-1465.

Tolay, E., Sürgevil, O., ve Topoyan, M. (2012) “Akademik Çalısma Ortamında Yapısal ve Psikolojik Güçlendirmenin Duygusal Bağlılık ve ìs Doyumu Üzerindeki Etkileri", Ege Akademik Bakış, 12(4): 449-465.

Turunç, Ö., ve Çelik, M. (2010) “Örgütsel Özdeşleşme Ve Kontrol Algılamalarının, Çalışanların İşten Ayrııma Niyeti Ve İş Performansına Etkileri", Atatürk Üniversitesi iktisadi Ve Idari Bilimler Dergisi, 24(3): 163-181. 
Tyler, T. R. (1989) “The Psychology of Procedural Justice: A Test of The Group-Value Model", Journal of Personality And Social Psychology, 57(5): 830-838.

Uçar, Z. (2015) "Kontrol algısı-psikolojik sahiplenme ilişkisi üzerinde algılanan aşırı vasıflılığın düzenleyicilik etkisi", International Journal of Applied Business and Management Studies; Vol. 1, No.1: 40-58.

Van Dyne, L.,ve Pierce, J. L. (2004) "Psychological Ownership and Feelings of Possession: Three Field Studies Predicting Employee Attitudes and Organizational Citizenship Behavior", Journal of Organizational Behavior, 25(4): 439-459.

Vandewalle, D., Van Dyne, L., ve Kostova, T. (1995) "Psychological Ownership: An Empirical examination of Its Consequences", Group \& Organization Management, 20(2): 210-226.

Van Dyne, L., Cummings, L.L., ve Parks, J.M., (1995) "Extra-Role Behaviors: In Pursuit of Construct and Definitional Clarity" (A bridge over muddied waters). In L. L. Cummings \& B. M. Staw (Eds.), Research in organizational behavior (Vol. 17, pp. 215-285). Greenwich, CT: JAI Press.
Wagner, S. H.,Parker, C. P., ve Christiansen, N. D. (2003) "Employees That Think and Act Like Owners: Effects of Ownership Beliefs and Behaviors on Organizational Effectiveness" Personnel Psychology, 56(4): 847-871.

Yeşil, Ü., Bancar, A., ve Budak, G. (2015)“Psikolojik Sahiplik Kavramına Illişkin Bir Literatür Incelemesi", Eskişehir Osmangazi Üniversitesi Sosyal Bilimler Dergisi, 16(2): 59-82.

Yildiz B., Yildiz H. (2015) "The Effect of Servant Leadership on Psychological Ownership: The Moderator Role of Perceived Organizational Support", Journal Of Global Strategıc Management, Sayl: 9, 65-77.

Yildiz B., Alpkan L., Ateş H., Sezen B. (2015) "Determinants of Constructive Deviance: The Mediator Role of Psychological Ownership", Internatıonal Busıness Research, Sayı:8, 107-121.

Zhu, H.,Chen, C. C., Li, X., \& Zhou, Y. (2013) "From Personal Relationship to Psychological Ownership:The Importance of Manager-Owner Relationship Closeness in Family Businesses", Management and Organization Review, 9(2): 295-318. 
